\title{
Intermediation for Development: A New Index with a New Prospect
}

\author{
Ali Massoud ${ }^{1,2}$ \\ ${ }^{1}$ Professor of Economics at Sohag University, Egypt. \\ ${ }^{2}$ Research Fellow at Central European University, Hungary. \\ Correspondence: Ali Massoud, Professor of Economics at Sohag University, Egypt.
}

\author{
Received: May 5, 2015 \\ Accepted: May 20, 2015 \\ Available online: June 25, 2015 \\ doi:10.11114/aef.v2i3.910 \\ URL: http://dx.doi.org/10.11114/aef.v2i3.910
}

\begin{abstract}
:
This paper presents a construction of a new index that measures the role of banks in supporting pro-development activities and poverty alleviation. The index is called "Intermediation for Development Index (IFDI)". It consists of four sub-indices (dimensional indices). The first sub-index is the Size Index (SI). It measures the size of a bank by its total assets and total deposits. The second sub-index is the Financial Intermediation Index (FII). It measures the function of a bank as a financial intermediary. The third sub-index is the Financial Orientation Index (FOI). It measures to what extent a bank is oriented to corporate vs. retail finance. The fourth sub-index is the Regional Orientation Index (ROI). It measures to what extent a bank is oriented to provide finance to the poorest region in the country.
\end{abstract}

Keywords: financial intermediation, intermediation of development index, banks, and financial intermediaries.

\section{Introduction}

As the theory of financial intermediation explains, its foundation lies on reducing transaction costs and the existence of asymmetric information. Thus, financial intermediation facilitates the flow of money from agents that have excess of finance to those that want money to meet their financial needs. The process of intermediation enhances economic growth \& development by providing finance needed to establishing new firms, extending existing ones, and transferring creative ideas into businesses. Financial intermediaries are the core of financial markets \& systems which are the back bone of contemporary economies. The general consensus among economists nowadays is that financial market development makes a difference in the process of economic development. Banks are the oldest and the most important element among financial intermediaries. Even though there is an argument on the declining role of banks in the financial systems in developed countries and the movement of the contemporary financial systems toward being market-based instead of being bank-based systems, banks still the core of any financial system. Cetorelli, et al. (2012) provides a review of the evolution of banks and financial intermediation.

At the micro level, many studies have been conducted in the areas of banks' profitability, efficiency, risk management, capitalization, regulation,...etc. I argue that even though all these studies are important and they construct our understanding of the evolution of the businesses models that banks have followed, they failed to make a sound understanding of the main role of banks as intermediaries and connecting this role with economic growth \& development. At the macro level, banks have been studied and linked to economic growth and the process of economic development in two ways. First, when economists study financial development \& liberalization and their impacts on economic growth. Second, when economists study the causes of financial crises. Moreover, Adrin and Shin (2010) reconsider the role of financial intermediaries in monetary economics. They highlighted the importance of tracking balance sheet quantities for the conduct of monetary policy.

Up to my knowledge, there are no studies that deal with the issue of banks as financial intermediaries with the purpose of connecting their intermediation role to the process of economic development and other important issues such as poverty alleviation. Thus, by doing so, this paper fills an important gap in the existing literature. The objective of this paper is presenting new index that measures the role of banks as financial intermediaries in supporting activities proven to have a positive impact on economic growth and poverty alleviation. I call this new index "Intermediation for Development Index (IFDI)". Constructing such index is expected to contribute to our understanding of the behavior of banks in the framework of the enhancement of their role in economic development and poverty alleviation. IFDI is 
expected to help policymakers in developing \& underdeveloped countries to make the best use of their banks in the process of achieving economic development and alleviating poverty.

The remainder of the paper proceeds as follows. Section (2) presents a brief review of literature. Section (3) provides a detailed presentation of IFDI. Section (4) explains the construction process of IFDI. Section (5) gives a numerical example of IFDI's calculation. Section (6) summarizes the conclusion and the policy implications of constructing IFDI as a new index.

\section{Literature Review}

Even though there is no research allocated to develop an index that measures the role of banks as financial intermediaries that focuses on pro-development activities, e.g. financing new firms and expending the existing ones, a substantial effort has been spent in order to understand different aspects of banks as financial intermediaries. The rest of this section is allocated to provide a brief review of the studies that investigated various aspects of banks as financial intermediaries.

Capelle-Blancard, et al. (2008) presented a new calculation of intermediation ratios. Their calculation based on the breakdown of the total financial intermediation ratio into the sum of the credit intermediation ratio and the market intermediation ratio. The denominator of the ratio is obtained by adding loans and claims issued by the nonfinancial sector. While the numerator consists of two components: the first one is called credit intermediation and measured by the total of loans granted by domestic private and public financial institutions. The second component is called market intermediation and measured by the sum of claims issued by nonfinancial sector and submitted by domestic financial institutions. Their calculation of intermediation ratio allows for the capturing of the changes in the nature of the financial structure in terms of bank-based vs. market-based financial market.

Beck, et al. (1999) examined the relationship between the level of financial intermediary development and: economic growth, total factor productivity growth, physical capital accumulation, and private saving rates. The study used two indicators as measures for the level of development of financial intermediary. (1) The ratio of the liquid liabilities of the financial system to GDP. (2) The ratio of private credit to GDP. The study found a positive impact of financial intermediary's development level and the total factor productivity growth. However, the study did not find a strong evidence of the impact of financial intermediary's development level and other variables mentioned above.

Allen and Santomero (2001) investigated the role of banks as financial intermediaries in the US. The paper presented evidence that the traditional banking business of accepting deposits and making loans has declined significantly. Banks switched their activities to fee-producing activities. The paper explained this trend by the increasing development of financial markets in the US.

Schmidt, et al. (1997) examined whether there is a general trend toward disintermediation, which means that banks' importance in the financial sector declines, or not. The study was applied on three major European economies: France, Germany, and the UK. They found no evidence for disintermediation in the three economies. However, they found a sign of transformation of the financial system in France from a bank-based to a market-based financial system.

\section{The Intermediation for Development Index (IFDI): an overview}

In this section, I introduce a new index that I call the "Intermediation for Development Index (IFDI)". The IFDI is designed to measure the role of banks as financial intermediaries in supporting economic development and poverty alleviation. The index consists of four sub-indices as follows:

The first sub-index is the Size Index (SI) that measures the size of a bank by its total assets and total deposits. The larger the size of a bank is, the greater the role it plays as a financial intermediary. The amount of deposits in a bank indicates its ability to attract money from clients that have excess of financial resources and they prefer to save them in a bank and gain interest on them. Deposits is considered as the main determinant for the size of a bank. The larger the amount of deposits a bank receives, the larger is the size of this bank. Also, the size of a bank is usually measured by its total assets. Where there is a positive relationship between a bank's total assets and its size.

The second sub-index is the Financial Intermediation Index (FII) that measures the function of a bank as a financial intermediary. FII is calculated by using the total finance \& facilities as a percentage of total deposits and the income from finance \& facilities as a percentage of the total income. The importance of including the percentage of total finance \& facilities to the total deposits as an indicator in calculating FII comes from its direct expression of the real meaning of financial intermediation. It simply shows how much finance do banks provide to their customers who need finance relative to how much their customers who have excess of financial resources deposit money in them? If the percentage of total finance \& facilities to deposits in a specific bank is $70 \%$, it means that out of every 1000 L.E. deposits this bank receives from its customers who have excess of financial resources, it provides 700 L.E. as finance \& facilities to its other customers who have a shortage of finance. While if the percentage of total finance \& facilities to 
total deposits is only $30 \%$, it means that out of every 1000 L.E. deposits that the bank receives from its customers who have excess of financial resources, it provides only 300 L.E. in form of finance and other facilities to its customers who have a shortage in finance. Regarding the inclusion of the percentage of income that comes from finance \& facilities activities of the total income, this indicator indicates the importance of finance \& facilities as income-generating activities in a bank and to what extent this bank concentrates on these activities relative to other activities, e.g. purchasing government treasury bills. The higher the percentage of income that comes from finance \& facilities of the total income in a bank is, the greater is the role of this bank as a financial intermediary.

The third sub-index is the Financial Orientation Index (FOI) that measures to what extent a bank is oriented to corporate vs. retail finance. FOI is calculated using the total corporate finance as a percentage of total finance \& facilities. We assume that the larger the amount of finance that goes to corporates activities relative to the amount of finance that goes to retail in a banks is, the greater is the role that this bank plays in supporting development. On the one hand, many studies have shown that a substantial percentage of the retail finance goes to financing consumption needs of the beneficiaries. In many cases this behavior has led to financial difficulties for beneficiaries and even deepen the poverty in many developing countries. Massoud (2013) provides a detailed review for literature for this argument. On the other hand, the finance that goes to corporates is used to finance new firms or extending the operations of the existed firms. Thus, financing corporates lead to a larger role of enhancing economic development than financing retailers.

The fourth sub-index is the Regional Orientation Index (ROI) that measures to what extent a bank is oriented to provide finance to the poorest region in the country. As poverty is considered a major problem that faces the global economic agenda and a major issue in many developing and underdeveloped countries, including this indicator in our index captures the role of banks in poverty alleviation. The optimal way to capture the role of a bank in poverty alleviation is to look at the percentage of its finance that goes to the poor of its total finance to its clients. However, in practice, doing so is extremely difficult. Thus, we use the percentage of the finance that goes to the poorest region in a country as a proxy of the finance goes to the poor. Even if finance lays in hands of the rich and the corporates in a poor region, defiantly the poor are going to be benefited from these finance in terms of employment and increasing the demand of products produced by the poor.

\section{Calculating the IFDI}

To calculate the IFDI, I used the following equations.

\subsection{Dimensional Indices (sub-indices) are calculated by the following equation:}

Dimensional index $($ sub-index $)=($ actual Value - minimum value $) /($ maximum value - minimum value $)$

The minimum value is set ether at the lowest level of the value of the indicators according to the historical data or at the lowest requirement by laws \& rules. For instance, in order to open a new bank, the owners must allocate a minimum amount of capital. In this case, we can use the minimum amount of capital as the minimum value of the bank's size. Regarding the maximum value, it is set either by the upper bound of the indicators that their values are never going to be higher than them or by the highest observed values for these indicators, according to the historical data. For instance, the retail finance as a percentage of total finance in a specific bank cannot exceed $100 \%$ of the total finance. However, the observed maximum value for the indicator is more important whenever the maximum value is not expressed by a $100 \%$. Thus, in the case of banks the observed maximum values for the indicators is the appropriate form to be used in the calculation of the dimensional indices.

4.2 Combined SI and FII are calculated by the following equation:

$$
\text { Combined index }=\left\{\left(\mathrm{SUBI} 1^{1 / 2} * \mathrm{SUBI} 2^{1 / 2}-\mathrm{MinV}\right) /(\mathrm{OMaxV}-\mathrm{MinV})\right\}
$$

While SUBI1, SUBI2, MinV, and OMaxV denote sub-index1, sub-index2, minimum value, and the observed maximum value, respectively. We should mention that we can assign different weights for the sub-indicators.

4.3 The combined IFDI is calculated by the following equation:

$$
\mathrm{IFDI}=\mathrm{SI}^{1 / 4} * \mathrm{FII}^{1 / 4} * \mathrm{FOI}^{1 / 4} * \mathrm{ROI}^{1 / 4}
$$

However, we can assign different weights for the different dimensions.

A geometric mean is used in equations (2) and (3). The geometric mean of a data $\operatorname{set}\left\{a_{1}, a_{2}, \ldots, a_{n}\right\}$ is calculated by the following equation:

$$
\text { G-Mean }=\left(\prod_{i=1}^{n} a_{i}\right)^{1 / n}=\sqrt[n]{a_{1} a_{2} \cdots a_{n}} .
$$

The reason behind using the geometric mean instead of a simple arithmetic mean in calculating IFDI is that it takes into 
account differences in achievement across sub dimensions (sub-indices) when we calculate the dimensional indices SI and FII. Similarly, it takes into account differences in achievements across dimensions when we calculate IFDI using the dimensional indices SI, FII, FOI, and FOR as the above equations show. Unlike arithmetic mean, using geometric means makes the substitutability across dimensions imperfect which means that a low performance of a bank in a specific dimension cannot be compensated by a high performance in another dimension. Also, using the geometric mean ensures that a 1 percent decline in say F\&F (as \% of deposits) has the same impact on the IFDI as a 1 percent decline in say corporate finance (as \% of total F\&F). Fleming and Wallace (1986) proved that using geometric means is better than using arithmetic means in cases similar to the calculation of IFDI.

Finally, Ln values were used in calculating SI.

The following chart summarizes the process of FDI's calculation.

\begin{tabular}{|l|}
\hline 1- Total Assets \\
2- Total \\
Deposits \\
\hline
\end{tabular}

\begin{tabular}{|l|l|}
\hline $1-F \& F(\%$ of \\
deposits) \\
$2-$ Income from \\
$F \& F(\%$ of total \\
income)
\end{tabular}
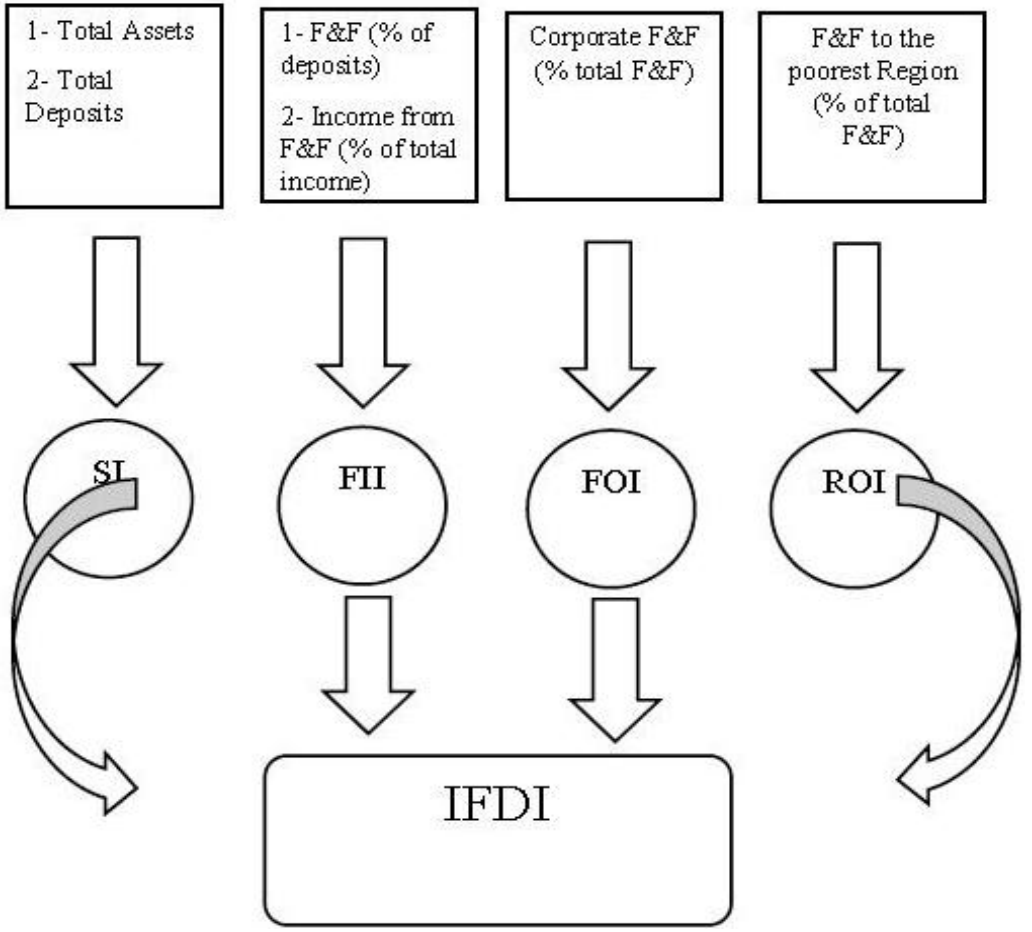

\section{A Numerical Example of IFDI's Calculation}

This section presents a numerical example of the process of IFDI's calculation. Assuming that there are three banks: A, $\mathrm{B}$, and C. In order to calculate the IFDI of these banks, the following steps should be conducted.

The First step is calculating the actual values of all indicators using the banks' balance sheets and income statements. Let's assume that the calculations' results are as appear in table (1).

Table 1. Some indicators for three banks (A, B, and C)

\begin{tabular}{|c|c|c|c|c|}
\hline $\begin{array}{l}\text { Dimension \& Indicator } \\
\text { / Bank }\end{array}$ & Component & A & B & $\mathrm{C}$ \\
\hline \multirow[t]{4}{*}{ SI } & Total Assets & 600 & 500 & 200 \\
\hline & (Billion \$.) & & & \\
\hline & Total Deposits & 460 & 350 & 150 \\
\hline & (Billion \$.) & & & \\
\hline \multirow[t]{2}{*}{ FII } & Total Finance and Facilities (\% of total deposits) & 35 & 55 & 40 \\
\hline & Income from Finance and Facilities ( $\%$ of total income) & 85 & 95 & 82 \\
\hline FOI & $\begin{array}{l}\text { Finance and Facilities to Corporates ( } \% \text { of total finance } \\
\text { and facilities) }\end{array}$ & 50 & 97 & 80 \\
\hline
\end{tabular}


ROI

Finance and Facilities to the Poorest Region ( \% of total

12

10

15

finance and facilities)

The second step is identifying the maximum and minimum values for all indicators as explained in section (4). The following table shows an example of this step.

Table 2. The actual minimum and maximum values for the required indicators.

\begin{tabular}{|c|c|c|c|}
\hline Dimension / Indicator & omponent & $\begin{array}{l}\text { Maximum/Obs } \\
\text {. Maximum }\end{array}$ & Minimum \\
\hline \multirow[t]{2}{*}{ SI } & Total Assets (Billion \$.) & 750 & 100 \\
\hline & Total Deposits (Billion \$.) & 560 & 65 \\
\hline \multirow[t]{2}{*}{ FII } & Total Finance and Facilities (\% of total deposits) & 60 & 15 \\
\hline & Income from Finance and Facilities ( $\%$ of total income) & 100 & 80 \\
\hline FOI & $\begin{array}{l}\text { Finance and Facilities to Corporates ( } \% \text { of total finance and } \\
\text { facilities) }\end{array}$ & 100 & 20 \\
\hline ROI & $\begin{array}{l}\text { Finance and Facilities to the Poorest Region ( } \% \text { of total } \\
\text { finance and facilities) }\end{array}$ & 20 & 0 \\
\hline
\end{tabular}

The third step is calculating the dimensional indices. Tables (3), (4), (5) and (6) in the appendix summarize the calculation process of SI, FII, FOI, and ROI, respectively.

Table 3. The Calculation of SI

\begin{tabular}{|c|c|c|c|c|}
\hline $\begin{array}{l}\text { Dimension \& \& } \\
\text { Indicator / Bank }\end{array}$ & Component & A & B & $\mathrm{C}$ \\
\hline \multirow[t]{5}{*}{ SI } & $\begin{array}{l}\text { Total Assets } \\
\text { (Billion \$.) }\end{array}$ & $\begin{array}{l}\operatorname{Ln}(600)-\ln (100) / \\
\operatorname{Ln}(750)-\ln (100)\end{array}$ & $\begin{array}{l}\operatorname{Ln}(500)-\ln (100) / \\
\operatorname{Ln}(750)-\ln (100)\end{array}$ & $\begin{array}{l}\operatorname{Ln}(200)-\ln (100) / \\
\operatorname{Ln}(750)-\ln (100)\end{array}$ \\
\hline & & $=0.889$ & $=0.799$ & $=0.344$ \\
\hline & $\begin{array}{l}\text { Total Deposits } \\
\text { (Billion \$.) }\end{array}$ & $\begin{array}{l}\operatorname{Ln}(460)-\ln (65) / \\
\operatorname{Ln}(560)-\ln (65)\end{array}$ & $\begin{array}{l}\operatorname{Ln}(350)-\ln (65) / \\
\operatorname{Ln}(560)-\ln (65)\end{array}$ & $\begin{array}{l}\operatorname{Ln}(150)-\ln (65) / \\
\operatorname{Ln}(560)-\ln (65)\end{array}$ \\
\hline & & $=0.909$ & $=0.782$ & $=0.388$ \\
\hline & $\begin{array}{l}\text { Assume that the } \\
\text { observed } \\
\text { maximum and } \\
\text { minimum for SI } \\
\text { are: } 0.960 \text { and } \\
0.200, \\
\text { respectively. }\end{array}$ & $\begin{array}{l}= \\
\left\{(0.889)^{1 / 2} *(0.909)^{1 / 2}\right\}-0.200 \\
/ \\
\{(0.960)-(0.200)\} \\
=0.920\end{array}$ & $\begin{array}{l}= \\
\left\{(0.799)^{1 / 2} *(0.782)^{1 / 2}\right\}-0.200 \\
/ \\
\{(0.960)-(0.200)\}\end{array}$ & $\begin{array}{l}= \\
\left\{(0.344)^{\left.1 / 2 *(0.388)^{1 / 2}\right\}-0.200}\right. \\
/ \\
\{(0.960)-(0.200)\}\end{array}$ \\
\hline
\end{tabular}


Table 4. The Calculation of FII

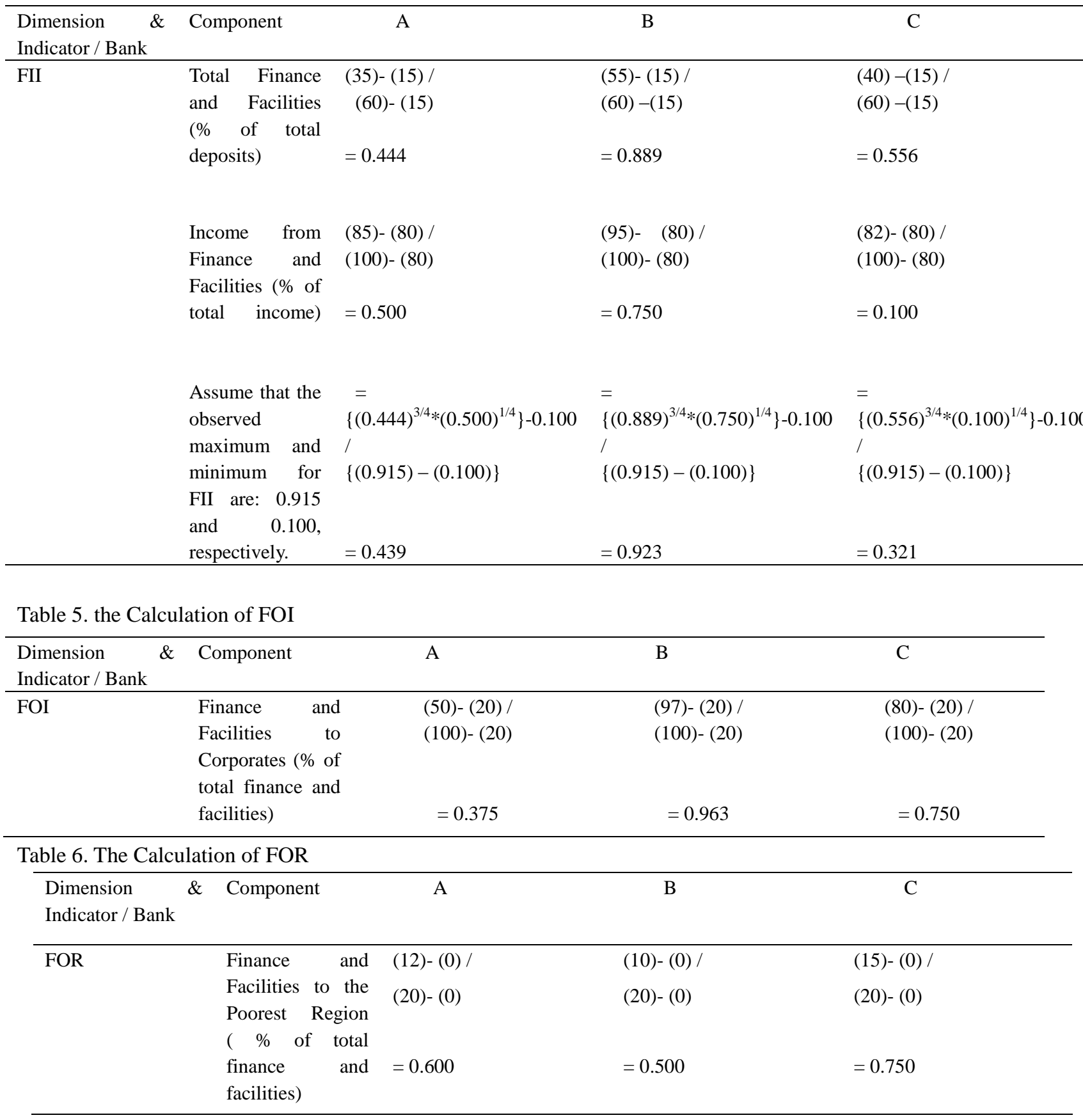

The fourth step is calculating the IFDI index. Table (7) in the appendix shows the calculation process of IFDI from the dimensional indices.

Table 7. the Calculation of IFDI

\begin{tabular}{lccc}
\hline $\begin{array}{l}\text { Dimension \& } \\
\text { Indicator / Bank }\end{array}$ & A & B & C \\
\hline SI & 0.920 & 0.777 & 0.218 \\
FII & 0.439 & 0.923 & 0.321 \\
ROI & 0.375 & 0.963 & 0.750 \\
FOR & 0.600 & 0.500 & 0.750 \\
\hline
\end{tabular}




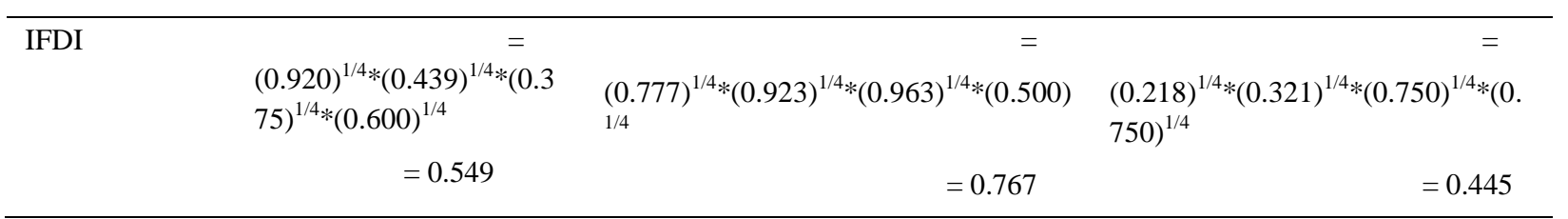

\section{Conclusion and Policy Implications}

This paper presents the construction process of a new index that measures the role of banks in supporting pro-development activities and poverty alleviation. The Index is called "Intermediation for Development Index (IFDI)". It consists of four sub-indices (dimensional indices). The first sub-index is the Size Index (SI). It measures the size of a bank by its total assets and total deposits. The second sub-index is the Financial Intermediation Index (FII). It measures the function of a bank as a financial intermediary. The third sub-index is the Financial Orientation Index (FOI). It measures to what extent a bank is oriented to corporate vs. retail finance. The fourth sub-index is the Regional Orientation Index (ROI). It measures to what extent a bank is oriented to provide finance to the poorest region in the country.

The policy implication of constructing this index is that it enables policy makers to assess the behavior of banks in their financial systems in terms of their pro-development activities and their contribution to poverty alleviation. Constructing this index is very important especially for developing and underdeveloped nations where financial systems are still bank-based systems. In the same time, poverty alleviation is a main challenge for policy makers and governments of these countries. Thus, constructing IFDI is expected to help governments in developing and underdeveloped countries to make a better use of their banking sector in achieving economic development and alleviating poverty.

\section{References}

Adrian, T., \& Shin, H. S. (2010). Financial Intermediaries and Monetary Economics. Federal eserve Bank of New Your, Staff Report ,98. http://dx.doi.org/10.1016/b978-0-444-53238-1.00012-0

Allen, F., \& Santomero, A. M. (2001). What do financial intermediaries do? Journal of Banking nd Finance, 25, 271-294. http://dx.doi.org/10.1016/S0378-4266(99)00129-6

Capelle-Blancard, G., Couppey-Soubeyran, J., \& Soulat, L. (2008). The measurement of financial intermediation in Japan. Japan and the World Economy, 20(1), 40-60. http://dx.doi.org/10.1016/j.japwor.2006.08.005

Cetorelli, N., Mandel B. H., \& Mollineaux, L. (2012). The evolution of banks and financial intermediation: framing the analysis. Federal Reserve Bank of New York, Economic Policy Review, 18(2).

Fleming, P. J., \& Wallace, J. (1986). How not to lie with statistics: the correct way to summarize benchmark results. Communications of the ACM , 29(3), 218-221. http://dx.doi.org/10.1145/5666.5673

Schmidt, R. H., Hackethal, A., Tyrell, M. (1997). Disintermediation and the Role of Banks in Europe: An International Comparison. Journal of Financial Intermediation, 8, 36-67. http://dx.doi.org/10.1006/jfin.1998.0256

Smith, J. E. (1988). Characterizing computer performance with a single number. Communications of the ACM, 31(10), 1202-1206. http://dx.doi.org/10.1145/63039.63043

\section{(cc) BY}

This work is licensed under a Creative Commons Attribution 3.0 License. 